\title{
Ten health stories that mattered this week: Feb. 2-6
}

- The Supreme Court of Canada unanimously struck down the ban on physician-assisted death to mentally competent patients who are suffering and deemed impossible to remedy or cure. The court ruled that the ban infringes on provisions for life, liberty and security of person in Section 7 of the Charter of Rights and Freedoms. Parliament has 12 months to draft new legislation. Physicians will not be compelled to assist

- Four measles cases in Toronto and a possible outbreak in Quebec prompted health officials across Canada to urge parents to vaccinate their children. "We know that vaccines are safe," Health Minister Rona Ambrose told $C B C$ News. "I believe this debate is almost bordering on the ridiculous at this point ... you're putting children who are more vulnerable than your own at risk of getting sick and potentially dying."

- British Columbia announced a new clinical intake process at 72 child and youth mental health offices that will allow young people in distress to see a clinician immediately, rather than go on a months-long waiting list. The province also launched an interactive online map of some 350 service providers and mental health intake offices to help young people find help near them.

- BC Member of the Legislative Assembly Adrian Dix asked the prov- ince to release the full, unredacted December 2014 report by an independent reviewer on the firing of seven health researchers in 2012. Of the seven workers fired, several have returned to their positions, two are pursuing wrongful dismissal suits and one researcher, Roderick MacIsaac, committed suicide in January 2013.

- Alberta New Democrats called the province's mental health care system among the worst in the country, citing an Alberta Health Services briefing note that outlines problems at hospitals across Edmonton. The document lists unsafe facilities, major capacity issues and safety risks to patients and front-line workers.

- The Wellesley Institute issued a scathing report on racism against indigenous people in the health care system, including pervasive and unconscious "pro-white bias" among health care workers that continues to harm Aboriginal health. Among possible solutions, the report recommends the creation of indigenousdirected health services, increased cultural sensitivity training and the use of indigenous patient navigators to serve as a bridge between patients and the system.

- The Ottawa Hospital and Winnipeg's Health Sciences Centre will conduct the Canadian arm of a large clinical trial studying the use of stem cells to treat multiple sclerosis. The trial is being conducted in nine countries with the aim of developing safe protocols for therapy involving mesenchymal stem cells, which have been shown to suppress inflammation and repair nerve tissue.

- Ontario Health Minister Dr. Eric Hoskins said hospitals in the province will adopt a "bundled" approach to care. This means patients will be paired with a care coordinator usually a registered nurse throughout their medical treatment. Pilot testing of the system found it improved patient outcomes and enabled patients to receive more care at home.

- Quebec's Liberal government confirmed it will invoke closure in order to force through controversial health care reforms. Bill 10 would see the administration of more than 100 health and social services centres merged into regional boards. Critics say the restructuring will slash hundreds of jobs and put English services at risk.

- Health union hearings got underway to reassign some 24000 Nova Scotia health workers into new bargaining units. Arbitrator Jim Dorsey gave the province the green light to slash the number of unions representing health workers from 50 to 4. - Lauren Vogel, CMAJ

CMAJ 2015. DOI:10.1503/cmaj.109-4992 